\title{
Semi-quantitative dot immunoassay for detection of IgM anti-dengue antibodies in human sera
}

\author{
Agus Sjahrurachman, Betty Ernawati, Fera Ibrahim, Mardiastuti, Tjahjani Mirawati Sudiro, Pratiwi Sudarmono
}

\begin{abstract}
Abstrak
Diagnosis laboratorik untuk infeksi virus dengue berperan penting dalam pengelolaan kasus dan pemberantasan penyakit. Sayangnya, cara diagnosis laboratorik yang ada saat ini sebagian besar lambat hasilnya dan sukar pengerjaannya. Dalam makalah ini dilaporkan hasil sementara uji coba format imunoesei noktah yang kami kembangkan untuk mendeteksi antibodi anti-dengue lgM secara semikuantitatifmenggunakan virus dengue terlabel biotin. Hasilnya menunjukkan bahwa cara baru ini mampu memberikan hasil dalam waktu 4,5 jam dan cukup sensitif, khususnya tuntuk infeksi sekunder.
\end{abstract}

\begin{abstract}
Laboratory diagnosis of dengue infection plays an important role for case management and disease control. Unfortunately, many of the available laboratory tests are not appropriate in terms of rapidity and simplicity. Here, we report a new format of semiquantitative dot immunoassay for detection of IgM-anti dengue antibodies in hunan sera employing biotinylated-dengue antigens which is simple in term of methodology and rapid in term of the test result. The results indicated that the new test is sensitive for diagnosis of secondary dengue infection. The test result can be obtained within four and a half hours.
\end{abstract}

Keywords: biotinylated-dengue, diagnosis, immunoassay

Dengue infection is prevalent in tropical region of Asia, America and Africa. ${ }^{1-4}$ Sporadic outbreaks have also occurred in subtropical regions of Australia, America, Asia and Africa. ${ }^{1,4}$ In other words, dengue infection is one among other major public health problems in many developing countries. On the other hand, it is well known that definite diagnosis of dengue infection is hardly determined solely on the basis of clinical signs and symptoms. Laboratory investigations is required in majority of cases. ${ }^{4,5}$

Several laboratory approaches to diagnose dengue infection in suspected cases have been developed. ${ }^{4,6-10}$ Virus isolation and polymerase chain reaction have been proved to be the most valuable methods for the viremic phase of acute stage. ${ }^{4,8,10}$ However, those methods are not appropriate to be routinely used in developing countries where laboratory facilities are relatively insufficient. Simpler laboratory method is needed for such developing countries. Here we report a new and simple laboratory method to diagnose den-

Department of Microbiology, Faculty of Medicine,

University of Indonesia, Jakarta, Indonesia gue infection in suspected cases employing biotinylated-dengue for IgM-anti dengue dot immunoassay.

\section{METHODS}

\section{Serum samples}

Serum samples were obtained from patients clinically diagnosed as dengue haemorrhagic fever and patients suffering from fever without any clinical symptoms and signs of respiratory, skin, gastrointestinal nor neurological disorders. Confirmation of dengue infection was done by haemagglutination inhibition (HI) test employing 4-8 HAU/0.025 $\mathrm{ml}$ of four types of dengue antigens on a microtiter plate based on Clarke and Casals method. ${ }^{7}$ Classification of immune response to dengue was done according to W.H.O criteria. ${ }^{4}$ Sera from volunteers without fever within the last three months were also collected.

\section{Biotinylation of dengue viruses}

Dengue 1 Mochizuki strain, dengue 2 New Guinea C strain, dengue $3 \mathrm{H} 87$ strain and dengue $4 \mathrm{H} 241$ strain 
viruses infected $\mathrm{C} 6 / 36$ monolayer cell culture fluid was clarified from cellular debris by low speed centrifugation. Viruses in supernatant fluid were precipitated by polyethylene glycol and centrifuged at $10,000 \mathrm{rpm}$ for 30 minutes. Viral pellet were resuspended in phosphate buffer saline and biotinylated by biotinyl-e-amidocaproic acid N-hydroxy succinimide ester (Boehringer Mannheimn Co.) for 3 hours at room temperature as previously described. ${ }^{11}$

\section{Dot Immunoassay employing biotinylated-dengue virus ( BDIA )}

BDIA was performed as described previously. ${ }^{12}$ Briefly, one microgram of anti human IgM was blotted on a piece of nitrocellulose paper (Hybond C, Amersham Co) which was blocked with $2 \%$ skimmed milk and air dried. Two hundred and fifty microliter of $1: 100$ time diluted test serum was then applied on the paper and incubated at room temperature for two hours. Reactions of IgM and a mixture of biotinylated-dengue as well as the mixture of biotinylated-dengue and horse-radish peroxidase-labelled streptavidin were done at room temperature for one hour each. Finally, 5-chloronaphthol substrate was added for color development. After 30 minutes at room temperature, the intensity of color (optical density) on the dot was measured at $490 \mathrm{~nm}$ wavelength with a portable computing reflection densitometer (Tobias Associates Inc, USA). The result of the test was also observed by naked eyes.

\section{RESULTS}

\section{Optical density ( OD ) of BDIA}

One hundred and forty six paired patients sera which had been subjected to HI tests were collected and tested by BDIA. They were 42 paired sera from patients without evidence of dengue infection ; 23 paired sera showing primary dengue infection, 48 paired sera showing acute secondary dengue infection and 33 paired sera showing recent secondary infection. The BDIA results showed that OD 490 from the sera obtained from healthy subjects and non-dengue subjects were very low compared to those from dengue patients as shown on Table 1 \& Figure 1. Further, observed by naked eyes all of the blot of the sera from healthy subjects and almost all sera from non dengue subjects were colorless. As to the blot of sera from dengue subjects, our observation indicated that $O D$ 490 of the sera taken from convalescent stage patients were higher than sera from acute stage patients.
Table 1. Optical density of BDIA on patient sera

\begin{tabular}{lll}
\hline Group of subject & Stage & $\begin{array}{l}\text { OD490 value } \\
\text { (Mean + SD) }\end{array}$ \\
\hline $\begin{array}{l}\text { Non-Dengue } \\
(\mathrm{n}=42)\end{array}$ & Acute & $0.09+0.027$ \\
Acute, primary dengue & Convalescence & $0.09+0.039$ \\
$(\mathrm{n}=23)$ & Acute & $0.118+0.077$ \\
$\begin{array}{l}\text { Acute, secondary dengue } \\
(\mathrm{n}=48)\end{array}$ & Acute & $0.165+0.102$ \\
Recent, secondary dengue & Convalescence & $0.148+0.079$ \\
$(\mathrm{n}=33)$ & Acute & $0.168+0.076$ \\
Healthy person & Convalescent & $0.176+0.076$ \\
$(\mathrm{n}=10)$ & & $0.06+0.026$ \\
\hline
\end{tabular}

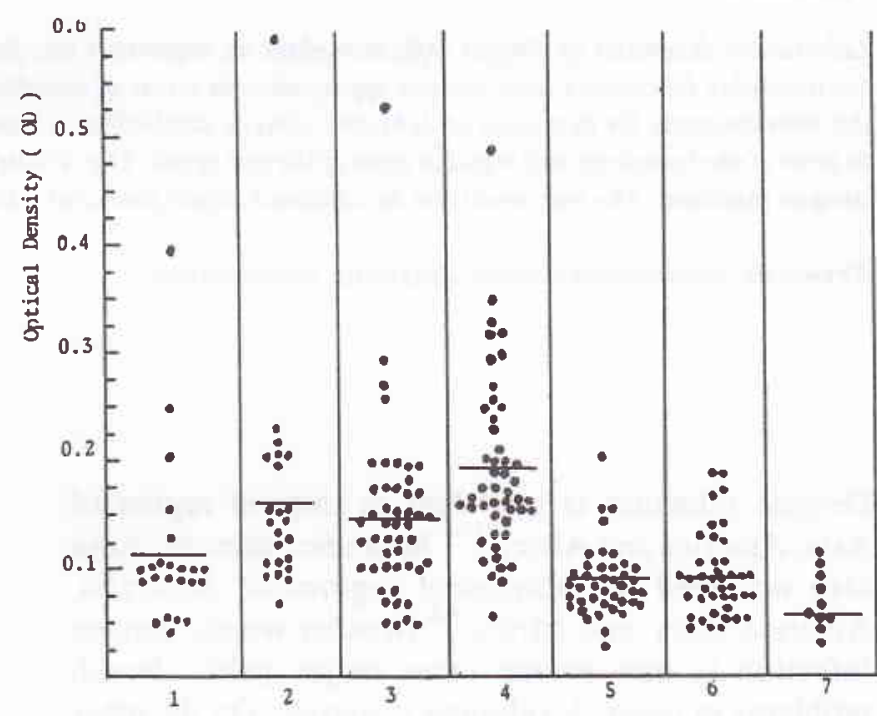

Figure 1. Serum specimens collected from primary dengue infection (lane 1 and 2 ), secondary dengue (lane 3 and 4 ), non-dengue infection (lane 5 and 6 ) and healthy persons (lane 7 ). Lane 1,3 and 5 indicate sera taken at acute stage and lane 2,4 and 6 indicate sera taken at convalescent stage of diseases. Optical density of the blot was measured by a handy densitometer. Bar indicates mean value of optical density.

\section{Positivity of BDIA}

Mean OD490 value of healthy persons plus two standard deviation was used as the cut off'value. Using this cut off, the specimen showing the OD value of minimum 0.11 was scored as positive while the specimen showing the OD value of less than 0.11 was scored as negative . Of 23 paired sera of primary dengue, $30.4 \%$ of the acute sera and $78.3 \%$ of the convalescent sera could be diagnosed as positive by BDIA. Of 48 paired 
sera of secondary dengue, $77.1 \%$ of the acute sera and $91.7 \%$ of the convalescent sera could be diagnosed as positive by BDIA. As for recent dengue cases, $72.7 \%$ of acute and $75.7 \%$ convalescent sera were scored as positive while only $19.0 \%$ of the acute and $23.8 \%$ of the convalescent sera showed positive results for nondengue cases. Details of data and typical results of BDIA are shown on Table 2 and Figure 2.

Table 2. Positivity of BDIA to detect IgM anti-dengue in human sera

\begin{tabular}{llc}
\hline Group of subject & \multicolumn{1}{c}{ Stage } & $\begin{array}{c}\text { BDIA } \\
\text { No. positive / total (\%) }\end{array}$ \\
\hline Non-Dengue & Acute & $8 / 42(19.0 \%)$ \\
$(n=24)$ & Convalescence & $10 / 42(23.8 \%)$ \\
Primary dengue & Acute & $7 / 23(30.4 \%)$ \\
(n=23) & Convalescence & $18 / 23(78.3 \%)$ \\
Acute, secondary & Acute & $37 / 48(77.1 \%)$ \\
dengue $(n=48)$ & Convalescence & $44 / 48(91.7 \%)$ \\
Recent, secondary & Acute & $24 / 33(72.7 \%)$ \\
dengue $(n=33)$ & Convalescent & $25 / 33(75.7 \%)$ \\
\hline
\end{tabular}

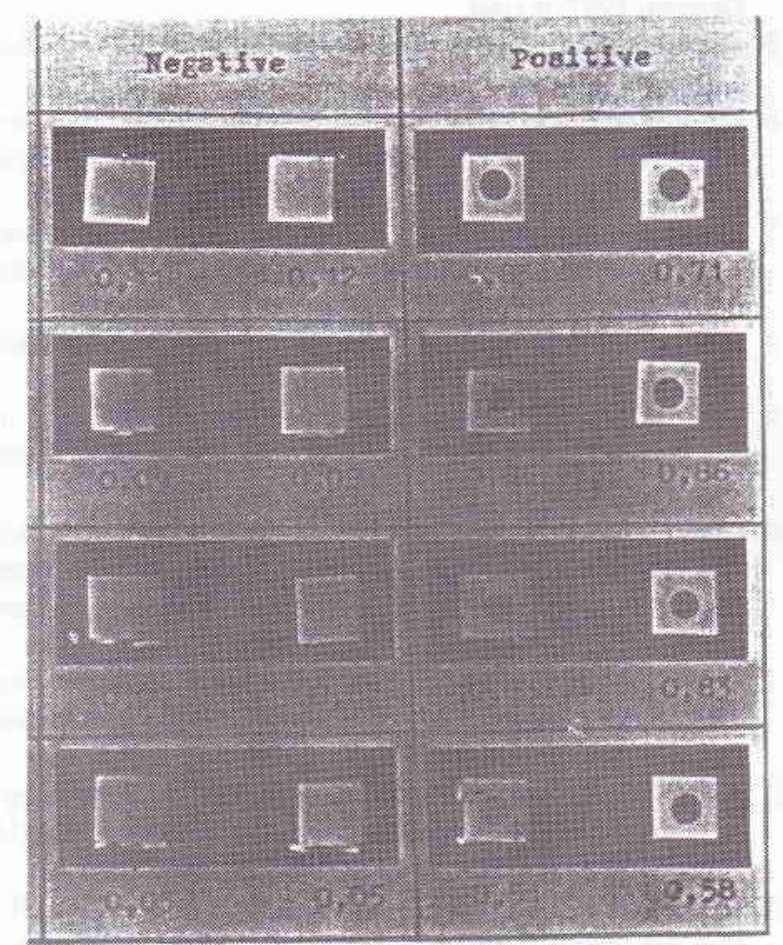

Figure 2. Sera from dengue-infected and dengue non-infected persons were subjected to BDIA. Optical density of the result was measured with handy densitometer. Number below the dots indicate optical density value.

\section{Relationship between duration of fever and DIA result}

In primary infection, only a few of the cases showed positive BDIA results when the sera were taken at day 5 of fever or earlier. Proportion of positive DIA increased on the sera taken at more than 5 day after the onset of fever. However, in secondary infection higher proportion of positive BDIA could be observed even though the sera were taken before 5 days of fever. Details of data are shown on Table 3 and Table 4.

Table 3. Correlation between duration of fever and BDIA result in primary infection

\begin{tabular}{ccc}
\hline $\begin{array}{c}\text { Day of } \\
\text { fever }\end{array}$ & $\begin{array}{l}\text { Proportion of cases } \\
\text { showing positive DIA } \\
\text { on acute sera }\end{array}$ & $\begin{array}{l}\text { Proportion of cases showing } \\
\text { positive DIA on convalescent } \\
\text { sera }\end{array}$ \\
\hline \multirow{2}{*}{$\begin{array}{c}\text { s. } \\
2\end{array}$} & $0 / 4(0 \%)$ & $0 / 0$ \\
3 & $0 / 1(0 \%)$ & $0 / 0$ \\
4 & $2 / 4(50 \%)$ & $0 / 0$ \\
5 & $0 / 2(0 \%)$ & $0 / 2(0 \%)$ \\
$>5$ & $1 / 2(50 \%)$ & $1 / 1(100 \%)$ \\
Unknown & $3 / 1(100 \%)$ & $12 / 12(100 \%)$ \\
\hline
\end{tabular}

Table 4. Correlation between duration of fever and BDIA result in secondary infection

\begin{tabular}{ccc}
\hline $\begin{array}{c}\text { Day of } \\
\text { fever }\end{array}$ & $\begin{array}{l}\text { Proportion of cases } \\
\text { showing positive DIA } \\
\text { on acute sera }\end{array}$ & $\begin{array}{l}\text { Proportion of cases showing } \\
\text { positive DIA on convalescent } \\
\text { sera }\end{array}$ \\
\hline 1 & $1 / 2(50 \%)$ & $0 / 0$ \\
2 & $3 / 5(60 \%)$ & $0 / 0$ \\
3 & $7 / 9(77.8 \%)$ & $0 / 0$ \\
4 & $7 / 7(100 \%)$ & $0 / 0$ \\
5 & $5 / 5(71.4 \%)$ & $1 / 1(100 \%)$ \\
$>5$ & $8 / 9(88.9 \%)$ & $58 / 41(92.7 \%)$ \\
Unknown & $6 / 9(66.7 \%)$ & $5 / 6(83.3 \%)$ \\
\hline
\end{tabular}

\section{DISCUSSION}

Several laboratory diagnostic techniques for dengue infection are available. Polymerase chain reaction and virus isolation are among the most valuable techniques in term of academic interest. ${ }^{4,8,10}$ Positive result of the test is indisputable. Those techniques, however, are not suitable for developing countries where laboratory facilities are relatively insufficient. Further, those techniques are time consuming and is not appropriate for field work especially in remote area. Because of such difficulties, W.H.O. recommends haemagglutination inhibition ( HI ) test as a routine test for diag- 
nosis of dengue infection. Unfortunately, however, interpretation of the $\mathrm{HI}$ test require a pair sera taken at least a week apart. Therefore, though HI test is practical in term of the methodology, conclusion of the result often cannot be drawn since after one week the infected cases may already be cured or passed away. On the other hand, it is well known that in any infectious diseases, humoral immune response is evoked. Further, IgM antibodies is one among other immune response that appear earlier in the course of the diseases. ${ }^{13}$ Detection of IgM-anti dengue in human sera therefore would be an interesting target to be elaborated. Here, we report a preliminary study on detection of an IgM-anti dengue in human using biotinylated-dengue.

The results indicate that IgM-anti dengue titer in dengue cases is higher compared to non-dengue cases. Further, IgM-anti dengue in the sera of acute dengue taken at convalescent stage is higher than at acute stage, indicating that the humoral immune responses to the infecting agents is switched on. On the other hand IgM-anti dengue in the sera of recent infection taken from acute and convalescent stages are not different, indicating that the humoral immune response has reached a plateau phase or viral replication in human body has recently ceased. The results also indicate that IgM-anti dengue in non-dengue cases is higher as compared to healthy persons. The latest finding reflect that majority of healthy persons enrolled in this study are immunologically virgin to dengue antigens while those of non-dengue cases has been in the past exposed to dengue antigen as indicated by the presence of anti dengue-haemaglutinin in their sera. Further, it has been well known that Indonesia is a dengue (hyper) endemic area ${ }^{14}$ and IgM-anti dengue in human sera may persist for several months. ${ }^{4}$

Employing cut off value of OD 0.11 , a possibility for using BDIA as diagnostic tool is explored. The result indicate that sensitivity of BDIA on acute sera from primary infection is low. The sensitivity of BDIA sharply increase on convalescent sera. Considering that majority of acute sera from primary infection are taken before day 5 of fever, our findings is consistent with previous findings which indicate that IgM-anti dengue in sera of primary infection could be detected when the sera is taken by or after day 5 of fever. ${ }^{4}$

Compared to primary infection, proportion of secondary infection cases showing positive BDIA are higher, reaching $91.7 \%$ at convalescent stage. Further, IgM-anti dengue in secondary infection can be detected earlier as compared to previous reports. ${ }^{15}$ The ability to earlier detect IgM anti dengue by our system, compared to previous reports, probably relate to the difference in sensitivity of the assay system.

\section{CONCLUSION}

BDIA is a simple test and require shorter time than the HI test. Further, BDIA has a high sensitivity especially for secondary dengue. Therefore, BDIA might be useful as routine diagnostic method especially for secondary dengue in developing countries. Additional study involving larger number of specimens is required to confirm the present findings.

\section{REFERENCES}

1. Gubler DJ. Arboviruses as imported diseases agents : The need for increased awareness. Arch Virol 1996; 11S:21-32.

2. Gubler DJ. Resurgent of vector-borne diseases. Emerg Infect $D$ is $1998 ; 4: 442-50$.

3. Lam SK. Emerging infectious diseases-South East Asia. Emerg Infect Dis 1998; 4:145-7.

4. World Health Organization. Dengue haemorrhagic fever. Diagnosis, Treatment, Prevention and Control. WHO Geneva, 1997; p 1-68.

5. Halstead SB. Dengue in health transition. Kaoshiung. J Med Sci 1994; 10S:2-14.

6. Cardosa MJ, Tio PH. Dot enzyme immunoassay : an alternative diagnostic aid for dengue and dengue haemorrhagic fever. Bull WHO 1991; 121:741-5.

7. Clarke DH, Casals J. Technique for haemagglutination and hemagglutination inhibition with arthropod-borne viruses. Am J Trop Med Hyg 1958; 7:561-73.

8. Henchal EA, Putnak JR. The dengue viruses. Clin Microbiol Rev 1990; 3:376-96.

9. Lam SK, Devi S, Pang T. Detection of specific IgM in dengue infection. SouthEast Asian J Trop Med Publ Health $1987 ; 18: 532-8$.

10. Lanciotti RS, Calisher CH, Gubler DJ, Chang GJ, Vomdam AV. Rapid detection and typing of dengue viruses from clinical samples by reverse-transcriptase polymerase chain reaction. J Clin Microbiol 1992; 30:545-51.

11. Agus S, Tallei T, Betty E, Amin S, Pratiwi S. Biotin-labeled dengue virus for detection of $\operatorname{IgM}$ anti dengue antibodies. Indon J Clin Microbiol $1995 ; 7$ : 25-30.

12. Agus S, Betty E, Tjahjani MS, Amin S, Pratiwi S. Development of dot enzyme immunoassay for detection of IgM antidengue. Indon J Publ Health 1996; 3:208-14.

13. Heinzell FP, Root RK. Antibodies. In: Mandell GL, Douglas Jr RG, Bennett JE, editors. Principles and Practice of Infectious Diseases. New York: Churchill Livingstone Inc; 1990. p. 41-61.

14. Suroso. Kebijakan Nasional pada Demam Berdarah dengue. Cermin Dunia Kedokteran 1992; 81:14-6.

15. Laboratory diagnosis of dengue virus infection. Epidemiological News Bull $1993 ; 7$ : 37-40. 